Tropical Journal of Pharmaceutical Research, September 2007; 6 (3): 785-792

(C) Pharmacotherapy Group Faculty of Pharmacy, University of Benin

Benin City, Nigeria.

All rights reserved.

Review Article

Available online at http://www.tjpr.org

\title{
Health Benefits of Tea Consumption
}

\author{
VK Sharma ${ }^{1 *}$, A Bhattacharya ${ }^{2}$, A Kumar $^{3}$ and HK Sharma ${ }^{4}$ \\ ${ }_{1 *, 4}$ Vivek College of Technical Education, Bijnor (Utter Pradesh INDIA), ${ }^{2}$ Department of Pharmaceutical Sciences, \\ Dibrugarh University, Dibrugarh (Assam INDIA), ${ }^{3}$ Renssselaer Polytechnic Institute, Troy (USA)
}

\begin{abstract}
Tea is the most common beverage after water. It is extracted from the leaves of Camellia sinensis (family: Theaceae). It is consumed in different forms, namely, oolong, green, black and llex tea depending on post-harvest treatment and chemical components. Being rich in natural antioxidants, tea is reported to be used in the management of colon, esophageal, and lung cancers, as well as urinary stone, dental caries, etc. The present review focuses on the beneficial effects of tea consumption on human health.
\end{abstract}

Keywords: $\quad$ Antioxidants, Theaflavonoides, Anticaries, Ethanol intoxication, Tea consumption.

*Corresponding Author: +91 013422252200 E-Mail: v_k05s@rediffmail.com 


\section{INTRODUCTION}

Tea is one of the most consumed beverages of the world. Presently, it is cultivated in at least 30 countries around the world. Tea beverage is an infusion of the dried leaves of Camellia sinesis, a member of Theaceae family. It is an evergreen shrub or tree that can grow to a height of 30 feet, but is usually clipped to a height of 2.5 feet in cultivation. The tree or shrub is heavily branched with dark-green, hairy, oblong, ovate leaves cultivated and preferentially picked as young shoots. Older leaves are considered to be inferior in quality. Freshly harvested tea leaf is processed differently in different parts of the world to give oolong tea $(2 \%)$, green tea $(20 \%)$ or black tea $(78 \%)^{1}$. Green tea is prepared from the fresh tea leaf and widely consumed in Japan and China. Western cultures favour black tea which is prepared through the oxidation, curing process of maceration and exposure to atmospheric oxygen ${ }^{2,3}$. The consumption of oolong tea is mostly confined to China and Taiwan, and roasted tea is consumed mostly in Japan. Green and roasted teas are steamed, respectively, to avoid enzymatic oxidation; oolong tea is semi-fermented to permit a moderate level of enzymatic oxidation during processing ${ }^{2,4,5}$. Also, llex paraguayensis is a species of tea from South America. This plant is processed to obtain a final commercial product named yerba mate. The mate is a famous popular tea consumed in Argentina, Brazil, Uruguay, and Paraguay. Even though the therapeutic properties of yerba mate have been extensively explored, there are few studies of chemical composition of mate $e^{2,6,7}$.

'Healthy Foods' containing active scavengers of free radicals are very popular nowadays. Advertisements in newspapers and magazines regarding a "Wonder Cure" that prevent damage to the body are becoming ubiquitous. It is widely accepted that phenolic compounds contained in certain foods have potential health benefits. Tea is linked to beneficial effects on human health with the polyphenols as the responsible constituents $^{1,8,9}$.

Tea leaves as well as the resulting beverage tea are known to possess high amounts of polyphenols, especially flavanols, the so called catechins ${ }^{5,10}$. Many in vitro and in vivo effects of tea polyphenols have been reported ${ }^{11,12,13}$ including antioxidant, anticarcinogenic and hypolipidemic properties.

\section{Chemical composition of tea}

In making green tea, the tea leaves are heated to inactivate the enzymes and dried. Thus the constituents of the tea leaves are preserved in the dried tea leaves. When the tea leaves are brewed, for example $2.5 \mathrm{~g}$ in $250 \mathrm{ml}$ of hot water for 3 minutes, about $30 \%$ of the solid materials are extracted into water. The spray-dried powder of the water extract, known as green tea solids, has been used for animal experiments. All teas are rich in polyphenolic compounds which are also present in red wine, fruit and vegetables ${ }^{14}$.Fresh tea leaf is rich in water soluble polyphenols, particularly flavanols, flavanol gallate and flavanol glycosides ${ }^{2,15,16}$. The major tea catechins: $\alpha$-epigallocatechin-3-gallate (EGCG), a-epigallocatechin (EGC), aepicatechin-3-gallate (ECG), $\alpha$-epicatechin (EC), a-epicatechin-3-gallate (ECG), $\alpha$-epicatechin (EC), $\alpha$-gallocatechin and $\beta$-catechin; constitutes $30 \%$ to $42 \%$ of the green tea solids by weight ${ }^{17}$.Caffeine accounts for $3 \%$ to $6 \%$. The composition varies with the cultivation conditions and subsequent processing of the tea. Black tea ('Black' used in this context relates solely to the method of leaf processing and not to the optional addition of milk to the beverage before consumption) is produced from fresh green leaf by 'enzymatic browning processes (driven by polyphenol oxidase) and coupled chemical oxidation of the flavanols and flavanol gallates and, to lesser extent, the flavanol (especially myricetin) glycosides and the non-flavanoid theagallin. These transformations produce a unique range of pigments including the brownish thearubigins and the red-orange theaflavins, theaflavic acids and theaflavins, as reviewed by Harbowy and Balentine ${ }^{18}$. The thearubigins are the major polyphenols of black tea leaf and beverage. Their content has been variously estimated as $3-6 \%$. In this process, commonly referred to as fermentation, the caffeine content in the tea leaves is not significantly changed. 
Theaflavins contribute to the taste, the bright red orange colour of black tea, and account for $2 \%$ to $6 \%$ of the dry weight of black tea extracts. The major theaflavins are theaflavin-3-digallate, theaflavin-30-gallate and theaflavin-3, 30digalalte.Black tea contains greater proportion of the complex catechins such as epigallocatechin gallate and other phenols such as theaflavins and the rubigins generated by the oxidation processes used in tea production ${ }^{19}$. Dall Orto et $\mathrm{al}^{9}$ reported the presence of flavonoids and phenolic compounds ( $p$-coumeric and ferulic acid) in about $10 \%$ of dry weight in yerba mate ${ }^{7}$.

\section{Tea with antioxidant property}

In human body, different protection mechanisms are present to combat free radicals. Also, there is equilibrium between pro-oxidative and antioxidant process, and when this equilibrium is disturbed in favour of free radicals, oxidation stress results ${ }^{20}$.The oxidation of lipoproteins plays an important role in the development of atherosclerosis by means of oxidation process, low density lipoproteins (LDL) of vascular walls. LDLs are very rich in cholesterol causing change in structure of vascular walls. These structural modifications encourage macrophages to pick up the oxidized LDL, promoting a change into foam cells. A collection of these cells in the vascular walls leads to the first noticeable change of cellular tissue, called fatty strreaks. These changes can result in the total closure of the artery, which could cause angina or vascular occlusion. It is well established that other pathological states such as cancer, rheumatoid arthritis, ischaemic reoxygenation injury of the liver and other organs, are set of by oxidation processes $^{20,21}$.

The powerful antioxidant properties of the tea are generally attributed to its flavonoid components; theaflavins, bisflavanols and theaflavic acids ${ }^{22}$. These compounds are all potent antioxidant in vitro and, when consumed, may act as the free radical scavengers which remove endogenously generated superoxide, peroxyl and hydroxyl radicals. The antioxidant property of tea is also associated with several other mechanisms e.g. depolarization of electrons, formation of intramolecular hydrogen bonds $^{23}$, rearrangement of the molecular structure ${ }^{24,25}$. These compounds may also prevent oxidative reactions by chelating free copper and iron, which may catalyze the formation of reactive oxygen species in vitro ${ }^{26,27}$.

The antioxidant flavanoids appear to be readily taken up by the human gastrointestinal tract. Van het Hoff et $\mathrm{al}^{28}$ have demonstrated that tea catechins, from both green and black teas, appear in human plasma and in circulating lipoprotein fractions ${ }^{28}$. Five cups of tea consumed at 2-hours intervals was sufficient to elevate plasma catechin concentrations by up to 12-fold in a UK based study. The consumption of black tea with milk did not impair the bioavailability of the tea catechins ${ }^{29}$. Maxwell and Thrope ${ }^{30}$ reported that tea consumption had no effect on total plasma antioxidant status ${ }^{30}$. Conversely, Serafini et $\mathrm{al}^{31}$ reported that green and black teas significantly elevated plasma antioxidant potential, as measured using a fluorescence assay. Beverage tea, rich in antioxidant polyphenols, affects host biochemistry and carcinogenesis at important target organs such as colon or mammary glands in rats ${ }^{32}$. This depletion of antioxidant power is observed with soya milk as well as cow's milk and in less marked with skimmed and semiskimmed milks. It suggests that the depletion of antioxidant effect is due to associations between the tea flavanoids and milk fat rather than proteins $^{3,33}$.

\section{Tea with anticancer property}

Many epidemiological, case-control, and cohort studies have been conducted to investigate the effects of tea consumption on human cancer incidence, and this topic has been reviewed by several authors ${ }^{34,35,36,37}$. In a Japanese cohort study, a negative association was found between green tea consumption and total cancer incidence, especially among females drinking more than 10 cups per day ${ }^{38}$. The effect of tea on stomach cancer has been the most extensively studied.. Of 15 studies, five casecontrol studies showed a protective effect of tea on the risk of stomach cancer ${ }^{39,40,41,42}$. Several studies have been done on tea drinking and colorectal cancer, with inconclusive or no 
evidence of an association. A recent study on middle-aged Finnish men indicated a positive association between increased green tea consumption and colon cancer risk ${ }^{43}$. However, the results with green tea showed a protective effect of tea ${ }^{36,37}$. A large study of pancreatic, colon, and rectal cancers indicated decreased incidents of these cancers with consumption of tea $^{44}$. The results from the epidemiological studies regarding tea intake and lung cancer are unclear because smoking factor was not taken into account in the study design. There is also some evidence that green tea polyphenols have a chemopreventive effect against cancers in smokers $^{45}$. The frequency of sister-chromatid exchange in lung cells was lower in smokers who consumed green tea. In a seven-year follow-up study of patients with breast cancer, it was found that increased consumption of green tea was associated with decreased numbers of axillary lymph node metastases especially among premenopausal patients with stage I and II breast cancers ${ }^{46}$. Early studies have linked tea drinking to both increased and decreased risks of esophageal cancers, but recent studies have shown that the positive association between tea and esophageal cancer was because of the high temperature at which the tea is consumed. Findings from the largest study of esophageal cancer conducted in China suggested that, barring the effect of temperature, drinking green tea decreases the risk of esophageal cancer ${ }^{47}$. The anti-carcinogenic activities of tea polyphenols are generally believed to be related to their antioxidative properties. Tea may affect the metabolism of carcinogens by induction or inhibition of various cytochrome P450s, but the practical importance of this mechanism is not known. Among the phase II enzymes, tea increases glucuronyl transferase activity, which may facilitate the detoxification pathway of certain carcinogens. Inhibition of tumor promotion-related enzymes, such as lipoxygenase and cyclooxygenase $e^{48,49}$, ornithine decarboxylase ${ }^{50,51,52}$, protein kinase $C^{52,53,54}$, and $5 \alpha$ steroid reductase isoenzymes ${ }^{35}$ has been shown. The antiproliferative effect of tea polyphenols has been demonstrated at both the initiation stage ${ }^{55}$ and the progression stage ${ }^{55}$ of lung tumorigenesis. In cell lines, EGCG and other tea catechins have been shown to inhibit cell growth and transformation. Some of these activities are believed to be attributable to the inhibition of MAP-kinases and AP-1 activities $^{56}, 57$. Fujiki et al $^{58}$ demonstrated that EGCG and other tea polyphenols inhibit growth of human lung cancer cells with a G2/M phase arrest of the cell cycle. The involvement of the tumor necrosis factor a pathway in the inhibition process has been suggested. EGCG and other tea polyphenols have been shown to inhibit the phosphorylation of $\mathrm{Rb}$ by $\mathrm{Cdk} 2 / 4^{59}$ and the binding of epidermal growth factor and TPA to their respective receptors and thus inhibit tumor promotion $^{59,60}$. Green tea polyphenols also enhance apoptosis, and this has been shown in many cancer cell lines such as PC-9, H661, KATO III, DU145, A431, LY-R, HaCaT, W138, and Molt- $43^{61}$. This study suggests that a prooxidative mechanism may be involved ${ }^{62}$. EGCG has also been shown to inhibit angiogenesis by inhibiting the growth of endothelial cells whereas green tea reduced significantly vascular endothelial growth factorinduced corneal neovascularization ${ }^{63}$.

\section{Green tea and ethanol intoxication}

The defense against long-term ethanol exposure is provided by both endogenously synthesised and exogenous antioxidants. The latter are derived from beverages and diet. The therapeutic effect of green tea is associated with its catechins. Catechins are polyphenols with two hydroxyl groups in the $B$ ring of the catechin molecule. These compounds possess the ability of preventing the formation of oxygen radicals, by inhibiting the activity of the enzymes involved in their generation. The liver is the richest source of xanthine oxidase, especially during ethanol metabolism ${ }^{64}$. Green tea extract inhibits the activity of xanthine oxidase in vitro, thus inhibiting superoxide anion generation ${ }^{65}$. Longterm ethanol exposure leads to an increase in the concentration of free ferrous ions which catalyze the Haber-Weiss reaction and hydroxyl radical generation and in result to an increase in lipid peroxidation. Catechins may diminish prooxidative action of transition metal ions by chelate formation. It is suggested that catechins can serve as scavengers of aqueous peroxyl 
radicals near the membrane surface while $\alpha$ tocopherol within the membrane ${ }^{66}$.

\section{Anticaries effect of tea}

With respect to the effect of tea extracts on dental caries, Oolong tea extract (OTE) has been reported to contain substances, notably polyphenols, that have antibacterial properties against oral pathogens, such as Streptococcus mutans, the bacteria closely associated with dental caries ${ }^{67,68}$. Some studies suggested that a diet supplemented with green tea may beneficial in dental caries management ${ }^{67,69,70}$. Lingstro"m et $\mathrm{al}^{71}$ found that frequent mouth rinsing with black tea infusion may contribute to oral health by inhibition of plaque, its acidity and its cariogenic microflora. Green tea and coffee contain varying amounts of fluoride ${ }^{72,73}$. Cariostatic properties of fluoride in water supply, dentifrices and topical gels have been documented $^{74,75}$. However, most of the reports suggest that the anti-caries effect observed with green tea is due primarily to the antibacterial properties of the organic components (polyphenols, tannins) rather than the cariostatic effect of fluoride ${ }^{69,76}$.

Tea contains substances, such as polyphenols, that were shown to have antibacterial properties against cariogenic bacteria, especially $S$. mutans ${ }^{77,78}$. The polyphenols in green tea were reported to have an inhibitory effect on growth and cellular adherence of Porphyromonas gingivalis, an oral bacterium that causes periodontal disease ${ }^{79}$.

\section{Other effects}

A cross-sectional study of 1276 older women 65 to 76 years) in the U.K. found that tea drinkers had significantly higher bone mineral density BMD) at the lumbar spine and hip than nondrinkers ${ }^{80}$. The mechanisms for a beneficial effect of tea consumption on bone mineral density are not clear. Although tea is a relatively good source of fluoride, an element known to increase bone density in pharmacologic doses, there is little evidence that the amount of fluoride supplied by tea would significantly affect $\mathrm{BMD}^{81}$.The oxidative stress-responsive transcription factor, NF- has been found recently to play a role in bone resorption, and increased levels of urinary 8-iso-PGF2 $\alpha$, a biomarker for oxidative stress, were significantly associated with decreased lumbar spine and total body BMD in a cross-sectional study of 101 men and women $^{82}$. Tea polyphenols could potentially inhibit bone resorption by decreasing $B$ activation, decreasing oxidative stress or inhibiting NF-.

High fluid intake, including tea intake, is generally considered the most effective and economical means of preventing kidney stones $^{83}$. However, tea consumption has been found to increase urinary oxalate levels in healthy individuals ${ }^{84}$, and some experts continue to advise those prone to calcium oxalate stone formation to limit tea consumption ${ }^{85}$.

\section{CONCLUSION}

Most of the effects of tea are associated with flavonoids and their antioxidant potential. These manifest counter acting power of body towards naturally generated or externally invaded oxidizing species. The polyphenols present in tea can also decrease the risk factor of specific type of cancers by inducing phase I and phase II metabolic enzymes that increase the formation and excretion of detoxified metabolites of carcinogens. The research interest based on tea components may provide an approach to decrease the incidence of and mortality from various diseases. Overall tea is an affordable beverage of natural origin compared to modern beverages such as soft drinks.

\section{REFERENCES}

1. Kuroda $Y$, Hara $Y$. Antimutagenic and anticarcinogenic activity of tea polyphenols. Mutat. Res. 1999, 436:69-97.

2. Graham HN. Green tea composition, consumption and polyphenol chemistry. Preventive Med.1992, 21:334-350.

3. Langley-Evans SC. Antioxidant potential of green and black tea determined using the ferric reducing power assay (FRAP). Int. J. Food Sci. Nutr. 2000, 51:181-188.

4. Balentine DA. Manufacturing and Chemistry of Tea. In: Ho CT, Huang MT, Lee CY (eds). Phenolic Compounds in Food and their Effects on Health I: Analysis, Occurrence, and Chemistry, American Chemical Society: Washington, DC, 1992; Vol. 8, pp 102-117. 
5. Balentine DA, Wiseman SA, Bouwens LCM. The chemistry of tea flavonoids. Crit. Rev. Food Sci. Nutr.1997; 37:693-704.

6. Kawakami M, Kovayashi A. Volatile Constituents of Green Mate and Roasted mate. J. Agric. Food Chem.1991; 39: 1275-1279.

7. Dall Orto VC, Vago GM, Carball RR, Rezzano IN. Comparison of Tyrosinase Biosensor and Colorimetric Method for Polyphenol Analysis in Different Kinds of Teas. Analyt. Lett. 2005; 38: 1933.

8. Riemersma RA, Rice-Evans CA, Tyrrell RM, Clifford $M N$, Lean ME. Tea flavonoids and cardiovascular health. Q. J. Med. 2001; 94: 277-282.

9. Mukhtar H, Ahmad N. Tea polyphenols: prevention of cancer and optimizing health. Am. J. Clin. Nutr.2000; 71: 1698S-1704S.

10. Lakenbrink C, Lapczynski S, Maiwald B, Engelhardt UH. Flavonoids and other polyphenols in consumer brews of tea and other caffeinated beverages. J. Agric. Food Chem.2000; 48: 28482852.

11. Vinson JA, Dabbagh YA, Serry MM, Jang J. Plant flavonoids, especially tea flavonols, are powerful antioxidants using an in vitro oxidation model for heart disease. J. Agric. Food Chem. 1995; 43: 2800-2802.

12. Vinson JA, Jang J, Yang J, Dabbagh $Y$, Liang $X$, Serry $M$, Proch J, Cai S. Vitamins and especially flavonoids in common beverages are powerful in vitro antioxidants which enrich low density lipoproteins and increase their oxidative resistance after ex vivo spiking in human plasma. J. Agric. Food Chem.1999; 47: 2502-2504.

13. Rice-Evans CA, Miller MN, Paganga G. Structureantioxidant activity relationships of flavonoids and phenolic acids: Free Radic. Biol. Med. 1996; 20: 933-956.

14. Hertog MG, Feskens EJM, Hollman PCH, Katan M, Kromhout $D$. Dietary antioxidant flavonoids and risk of coronary heart disease: the Zutphen Elderly Study. Lancet.1993b; 342: 1007-1011.

15. Willson KC, Clifford MN. Tea: Cultivation to Consumption (London: Chapman \& Hall) 1992.

16. Bors W, Heller W, Michel C, Stettmaier K. Flavonoids and polyphenols: Chemistry and biology. In.Cadenas E, Des, PL (eds.). Handbook of Antioxidants.New York: Marcel Dekker, Inc.,1996;409-466.

17. Chung S, Liao YJ, Yang GY, Lu G. Inhibition of lung tumorigenesis by tea. Exp.Lung Res.2005; 31:135-144.

18. Harbowy ME, Balentine DA. Tea Chemistry. CRC Crit. Rev. Plant Sci. 1997; 16: 415-480.

19. Van het Hof $K H$, de Boer HS, Wiseman SA, Lien $N$, Westrate JA, Tijburg LB. Consumption of green or black tea does not increase resistance of lowdensity lipoprotein to oxidation in humans. Am. J. Clin. Nutr. 1997; 66:1125-1132.

20. Rohdewald P. Pycnogenol. In. Rice-Evans CA, Packer $L$ (eds.). Flavonoids in Health and Disease, New York;Marcel Dekker, Inc., 1998;405-419.
21. Cross CE, Halliwell B, Borish ET, Pryor WA, Ames BN Saul RL, McCord JM, Harman D. Oxygen radicals and human disease. Ann. Intern. Med. 1987; 107:526.

22. Rice-Evans C. Implications of the mechanisms of action of tea polyphenols as antioxidants in vitro for chemoprevention in humans. Proc. Soc. Exp. Biol. Med.1999; 220:262-266.

23. Van Acker SABE, Van Den Berg DJ, Tromp MNJL, Griffioen $D H$, Van Bennekom WP, Van Der Vijgh WJF, Bast A. Structural aspects of antioxidant activity of flavonoids. Free Rad. Biol. Med. 1996; 20:331-342.

24. Salah N, Miller NJ, Paganga G, Tijburg L, Bolwell GP, Rice-Evans CA. Polyphenolic flavanols as scavengers of aqueous phase radicals and as chain-breaking antioxidants. Arch Biochem Biophys. 1995; 322:339-346.

25. Jovanovic S, Steenken S, Tosic M, Marjanovic B, Simic MG. Flavonoids as antioxidants. J Am Chem. Soc. 1994; 116:4846-4851.

26. Halliwell $B$. Antioxidants and human disease: a general introduction. Nutr Rev. 1997; 55:S44-S52.

27. Weisburger JH. Tea and Health: The underlying Mechanisms. Proc. Soc. Exp. Biol Med.1999; 220:203-209.

28. Van het Hof $K H$, Wiseman SA, Yang CS, Tijburg LBM. Plasma and lipoprotein levels of tea catechins following repeated tea consumption. Proc. Soc. Exp. Biol. Med. 1999; 220: 203- 209.

29. Cherubini A, Beal MF, Frei B. Black tea increases the resistance of human plasma to lipid peroxidation in vitro, but not ex vivo. Free Radic. Biol. Med. 1999; 27:381-387.

30. Maxwell S, Thorpe P. Tea flavonoids have little short term impact on serum antioxidant activity. Br. Med. J. 1996; 313:329.

31. Serafini $M$, Ghiselli A, Ferro-Luzzi A. In vivo antioxidant effect of green and black tea in man. Eur. J. Clin. Nutr. 1996; 50:28-32.

32. Chen W, Sohn SH, Fiala ES, Weisburger JH. Effect of tea on the formation of DNA adducts by azoxymethane. Xenobiot. 1998; 28(2): 213- 217.

33. Langley-Evans S.C. Consumption of black tea elicits an increase in plasma antioxidant potential in humans. Int. J. Food Sci. Nut.2000; 51:309-315.

34. Yang CS, Wang ZY. Tea and Cancer: A Review. J. Natl. Cancer Inst. 1993; 58: 1038-1049.

35. Liao S, Hiipakka RA. Selective Inhibition of Steroid 5 Alpha-reductase Isozymes by Tea Epicatechin-3gallate and Epigallocatechin-3-gallate. Biochem. Biophys. Res. Commun. 1995; 214: 833-838.

36. Kohlmeier L, Weterings KG, Steck S, Kok FJ. Tea and Cancer Prevention: An Evaluation of the Epidemiologic Literature. Nutr. Cancer. 1997; 27. 1-13.

37. Buschman JL. Green Tea and Cancer in Humans: $A$ Review of the Literature. Nutr. Cancer. 1998; 31:151-159.

38. Imai K, Suga K, Nakachi K. Lead Article: Cancerpreventive effects of drinking green tea among a 
Japanese population. Prev. Med. 1997; 26: 769775.

39. Kono S. Green Tea and Colon Cancer (letter to the editor). Jpn. J. Cancer Res. 1992; 83 (6): 669.

40. Yu GP, Hsieh CC. Risk Factors for Stomach Cancer: $A$ Population-based Case control Study in Shanghai. Cancer Causes Contrl. 1991; 2: 169-174.

41. Yu GP, Hsieh CC, Wang LY, YU SZ, Li XL, Jin TH. Green-Tea Consumption and Risk of Stomach Cancer: A Population-based Case-control Study in Shanghai, China. Cancer Causes Contrl. 1995; 6:532-538.

42. Memik F, Nak SG, Gulten M, Ozturk M. Gastric Carcinoma in Northwestern Turkey: Epidemiologic Characteristics. J. Environ. Pathol. Toxicol. Oncol. 1992; 11:335-338.

43. Hartman TJ, Tangrea JA, Pietinen $P$, Malila N, Virtanen $M$, Taylor PR, Albanes $D$. Tea and Coffee Consumption and Risk of Colon and Rectal Cancer in Middle-aged Finnish men. Nutr. Cancer. 1992; 31:41-48.

44. Ji BT, Chow WH, Hsing AW, McLaughlin JK, Dai Q, Gao YT, Blot WJ, Fraumeni JF, Jr. Green Tea Consumption and the Risk of Pancreatic and Colorectal Cancers. Int. J. Cancer. 1997; 70:255258.

45. Lee I.P, Kim YH, Kang MH, Roberts C, Shim JS, Roh JK. Chemopreventive Effect of Green Tea (Camellia sinensis) Against Cigarette Smokeinduced Mutations (SCE) in Humans. J. Cell. Biochem. Suppl. 1997; 27: 68-75.

46. Nakachi $K$, Suemasu $K$, Suga $K$, Takeo $T$, Imai $K$, Higashi $Y$. Influence of Drinking Green Tea on Breast Cancer Malignancy Among Japanese Patients. Jpn. J. Cancer Res. 1998; 89: 254-261.

47. Gao YT, McLaughlin JK, Blot WJ, Ji BT, Dai Q, Fraumeni JJ. Reduced Risk of Esophageal Cancer Associated with Green Tea Consumption. J. Natl. Cancer Inst. 1994; 86:855-858.

48. Katiyar S, Agarwal R, Wood GS. Inhibition of 12-Otetradecanoylphorbol- 13-acetate-caused Tumor Promotion in 7, 12-dimethylbenz (a) anthraceneinitiated SENCAR Mouse Skin by a Polyphenolic Fraction Isolated from Green Tea. Cancer Res. 1992; 52: 6890-6897.

49. Liu XD, Van Espen P, Adams F, Yan SH, Van belle $M$. Comparison of Tyrosinase Biosensor and Colorimetric Method for Polyphenol Analysis in Different Kinds of Teas. Anal. Chim.Acta. 1987; 200:421-430.

50. Katiyar SK, Agarwal R, Wang ZY, Bhatia AK, Mukhtar $H$. (2)- Epigallocatechin-3-gallate in Camellia sinensis Leaves from Himalayan Region of sikkim: Inhibitory Effects Against Biochemical Events and Tumor Initiation in Sencar Mouse Skin. Nutr. Cancer. 1992; 18: 73-83.

51. Huang $M T$, Ho CT, Wang ZY, Ferraro $T$, FinneganOlive T, Lou YR, Mitchell JM, Laskin JD, Newmark $H$, Yang CS, Conney $A H$. Inhibitory Effect of Topical Application of a Green Tea Polyphenol Fraction on Tumor Initiation and Promotion in
Mouse Skin. Carcinogenesis (Lond.). 1992; 13 : 947-954.

52. Hu G, Han C, Chen J. Inhibition of Oncogene Expression by Green Tea and (2)- epigallocatechin Gallate in Mice. Nutr Cancer. 1995; 24: 203-209.

53. Komori A, Yatsunami J, Okabe S, Abe S, Hara K, Suganuma $M$, Kim SJ, Fujiki $H$. Anticarcinogenic Activity of Green Tea Polyphenols. Jpn. J. Clin. Oncol. 1993; 23: 186-190.

54. Klaunig JE. Chemopreventive Effects of Green Tea Components on Hepatic Carcinogenesis. Prev. Med. 1992; 21: 510-519.

55. Yang GY, Liu Z, Seril DN, Liao J, Ding W, Kim S, Bondoc F, Yang CS. Black Tea Constituents, Theaflavins, Inhibit 4-(methylnitrosamino)-1-(3pyridyl)-1 Butanone (NNK)-induced Lung Tumorigenesis in A/J Mice. Carcinogenesis. 1997; 18: 2361-2365.

56. Dong Z, Ma WY, Huang C, Yang CS. Inhibition of Tumor Promoter-induced AP-1 Activation and Cell Transformation by Tea Polyphenols, (2)epigallocatechin Gallate and Theaflavins. Cancer Res. 1997; 57: 4414-4419.

57. Chung JY, Huang C, Meng X, Dong $Z$, Yang CS. Inhibition of Activator Protein 1 Activity and Cell Growth by Purified Green Tea and Black Tea Polyphenols in H-ras-transformed Cells: Structureactivity Relationship and Mechanisms Involved. Cancer Res. 1999; 59: 4610-4617.

58. Fujiki $H$, Suganuma $M$, Okabe $S$, Sueoka $N$, Komori A, Sueoka E, Kozu T, Tada $Y$, Suga K, Imai $K$, Nakachi K. Cancer Inhibition by Green Tea. Mutat. Res. 1998; 402: 307-310.

59. Liang YC, Lin-Shiau SY, Chen CF, Lin JK. Suppression of Extracellular Signals and Cell Proliferation through EGF Receptor Binding by (2) epigallocatechin Gallate in Human A431 Epidermoid Carcinoma Cells. J. Cell Biochem. 1997; 67: 55-65.

60. Kitano $K$, Nam $K Y$, Kimura S, Fujiki $H$, Imanishi $Y$. Sealing Effects of (2)-Epigallocatechin Gallate on Protein Kinase $C$ and Protein Phosphatase 2A. Biophys.Chem. 1997; 65 . 157-164.

61. Okabe S, Suganuma M, Hayashi M, Sueoka E, Komori A, Fujiki H. Mechanisms of Growth Inhibition of Human Lung Cancer Cell Line, PC-9, by Tea Polyphenols. Jpn. J. Cancer Res. 1997; 88: 639643.

62. Yang GY, Liao J, Kim K, Yurkow EJ, Yang CS. Inhibition of Growth and Induction of Apoptosis in Human Cancer Cell Lines by Tea Polyphenols. Carcinogenesis. 1998; 19: 611-616.

63. Cao Y, Cao R. Angiogenesis Inhibited by Drinking Tea. Nature. 1999; 398: 381.

64. Rouach H, Fataccioli V, Gentil M. Effect of chronic ethanol feeding on lipid peroxidation and protein oxidation in relation to liver pathology. Hepatol. 1997; 25:351-355.

65. Aucamp J, Gaspar A, Hara Y, Apostolides Z. Inhibibition of xantine oxidase by catechins from tea (Camalia sinensis). Anticancer Res. 1997; 17: 4381-4386. 
66. Skrzydlewska E, Ostrowska J, Stankiewicz A, Farbiszewski R. Green tea as a potent antioxidant in alcohol intoxication. Addiction Biol. 2002; 7: 307314

67. Kempler D, Anaise J, Westreich V, Gedalia I. Caries rate in hamsters given nonacidulated and acidulated tea. J. Dent. Res. 1977; 56: 89.

68. Hamilton-Miller JMT. Antimicrobial properties of tea (Camellia sinensis L.). Antimicrob. Agents Chemother.1995; 39: 2375-2377.

69. Onishi $M$, Shimura $N$, Nakamura $C$, Sato $M$. A field test on the caries preventive effect of tea drinking. J. Dent. Health.1981; 31: 13-19.

70. Sakanaka S, Aizawa M, Kim M, Yamamoto T. Inhibitory effects of green tea polyphenols on growth and cellular adherence of an oral bacterium, Porphyromonas gingivalis. Biosci. Biotech. Biochem. 1996; 60:745-749.

71. Lingstro"m $P, W u C D$, Wefel $C S$. In vivo effects of black tea infusion on dental plaque. J. Dent. Res. (Spec. Iss.).2000; 79: 593.

72. Pires MAF, Dantas ESK, Munita CS. Fluoride content of some teas consumed in Sao Paulo. Fluoride. 1996; 29: 144-146.

73. Fung KF, Zhang ZQ, Wong JWC, Wong MH. Fluoride contents in tea and soil from tea plantations and the release of fluoride into tea liquor during infusion. Environ. Pollut.1999; 104: 197-205.

74. Dean HT, Arnold FR Jr, Jay P, Knutson JW. Studies on mass control of dental caries through fluoridation of the public water supply. Publ. Health. Rep. 1950:65; 1403-1408.

75. Horowitz HS. The future of water fluoridation and other systemic fluorides. J. D ent. Res. (Spec. Iss.).1990; 69: 760-764.

76. Matsumoto M, Minami T, Sasaki H, Sobue S, Hamada S. Inhibitory effects of Oolong tea extract on caries inducing properties of mutans streptococci. Caries Res.1999:33:441-445.
77. Sakanaka S, Kim $M$, Taniguchi $M$, Yamamoto $T$. Antibacterial substances in Japanese green tea extract against Streptococcus mutans, a cariogenic bacterium. Agric. Biol. Chem.1989; 53:2307-2311.

78. Hattori $M$, Kusomoto IT, Namba $T$, Ishigami $T$, Hara $Y$. Effect of tea polyphenols on glucan synthesis by glucosyltransferase from Streptococcus mutans. Chem. Pharm. Bull. 1990; 38:717-720.

79. Sakanaka S, Aizawa M, Kim M, Yamamoto T. Inhibitory effects of green tea polyphenols on growth and cellular adherence of an oral bacterium, Porphyromonas gingivalis. Biosci. Biotech. Biochem.1996; 60: 745-749.

80. Hegarty VM, May HM, Khaw KT. Tea drinking and bone mineral density in older women. Am. J. Clin. Nutr. 2000; 71: 1003-1007.

81. Krall EA, Dawson-Hughes B. Osteoporosis. In: Shils M, (ed). Nutrition in Health and Disease, ed. 9, Baltimore,USA, Williams \& Wilkins, 1999, pp 1353-1364.

82. Basu S, Michaelsson $K$, Olofsson $H$, Johansson $S$, Melhus $H$. Association between oxidative stress and bone mineral density. Biochem. Biophys. Res. Commun. 2001; 288:275-279.

83. Borghi L, Meschi T, Schianchi T, Briganti A, Guerra A, Allegri $F$, Novarini $A$. Urine volume: stone risk factor and preventive measure. Nephron. 1999; 81 Suppl 1:31-37.

84. Massey $L K$, Roman-Smith $H$, Sutton RA. Effect of dietary oxalate and calcium on urinary oxalate and risk of formation of calcium oxalate kidney stones. J. Am. Diet. Assoc.1993; 93:901-906.

85. Massey LK. Tea oxalate. Nutr. Rev. 2000; 58:88-89. 